\title{
THE COMPLEXING ABILITY OF N-SUBSTITUTED THIOUREA DERIVATIVES AS CHELATING LIGANDS IN THE REACTION WITH PdCl ${ }_{2}$
}

\author{
Yu.L.Zborovskii ${ }^{1}$, V.V.Orysyk ${ }^{1}$, D.O.Melnychenko ${ }^{1}$, S.I.Orysyk ${ }^{2}$, H.H.Repich ${ }^{2}$, \\ L.V.Garmanchuk ${ }^{3}$, L.I.Palchykovska ${ }^{4}$, V.I.Pekhnyo ${ }^{2}$, M.V.Vovk ${ }^{1}$ \\ ${ }^{1}$ Institute of Organic Chemistry NAS of Ukraine, \\ 5, Murmanska Str., Kyiv, 02660, Ukraine. E-mail: zborovsky@ioch.kiev.ua \\ ${ }^{2}$ V.I.Vernadskii Institute of General and Inorganic Chemistry NAS of Ukraine \\ ${ }^{3}$ Educational and Scientific Centre "Institute of Biology" of Taras Shevchenko National University of Kyiv \\ ${ }^{4}$ Institute of Molecular Biology and Genetics NAS of Ukraine
}

Key words: $C=C$ double bond; palladium coordination compounds; thioureas; single crystal X-ray diffraction study; $\pi$-complexes; antitumor activity

\begin{abstract}
The complexation reactions of $\mathrm{N}$-substituted thiourea derivatives with $\mathrm{PdCl}_{2}$ have been investigated in the present work. The functionally substituted thiourea derivatives are found to be effective chelating agents, in which the nature of substituents has a significant impact to the compositions and structures of complexes. Thus, (N-pyridine-2-yl)thioureas in the interaction with $\mathrm{PdCl}_{2}$ form two types of complexes in the molar ratio of $M: L 1: 1$ and 1:2, in which they act as $\mathrm{S}, \mathrm{N}$-bidentate ligands coordinated to the palladium ion by thione sulphur and the nitrogen atom of the pyridine ring. The reaction of $\mathrm{N}$-allylthioureas with $\mathrm{PdCl}_{2}$ in the equimolar ratio results in formation of the $\pi$-complexes where the ligands are coordinated by the thione sulphur and the $C=C$ double bond of the allylic moiety. The preparative methods for the synthesis of this type of complexes have been developed. The composition of the products synthesized and the ligands coordination mode have been determined by elemental analysis and ${ }^{1} \mathrm{H} N \mathrm{MR}$ spectroscopy. Furthermore, the structure of compounds 4, 5 has been confirmed by the X-ray diffraction study. The biomedical studies have proven that the complex compounds 5 and 6 in vitro have the cytostatic and cytotoxic activity against tumour HeLa cells.
\end{abstract}

КОМПЛЕКСОУТВОРЮВАЛЬНА ЗДАТНІСТЬ N-ЗАМІЩЕНИХ ПОХІДНИХ ТІОСЕЧОВИНИ ЯК ХЕЛАТУЮЧИХ ЛІГАНДІВ У РЕАКЦІї 3 РD(II)

Ю.Л.Зборовський, В.В.Орисик, Д.О.Мельниченко, С.І.Орисик, Г.Г.Репіч, Л.В.Гарманчук, Л.І.Пальчиковська, В.І.Пехньо, М.В.Вовк

Ключові слова: $C=C$ подвійний зв'язок; координаційні сполуки паладію; тіосечовина; рентгеноструктурний аналіз; п-комплекси; протипухлинна активність

Досліджені реакції комплексоутворення $\mathrm{N}$-заміщених похідних тіосечовини з $\mathrm{PdCl}_{2}$. Встановлено, що функціонально заміщені похідні тіосечовини є ефрективними хелатуючими агентами, при цьому природа замісників суттєво впливає на склад і будову комплексних сполук. Так, (N-піридин-2-іл)тіосечовини при взаємодії з $\mathrm{PdCl}_{2}$ утворюють два типи комплексів у співвідношенні M:L 1:1 та 1:2, до складу яких ці реагенти входять як $S, N$-донорні бідентатні ліганди, координуючись до іона паладію атомом сірки тіонної групи та атомом азоту піридинового ядра. Реакція $\mathrm{N}$-алілтіосечовин із $\mathrm{PdCl}_{2}$ при еквімолярному співвідношенні реагентів приводить до утворення п-комплексів, в яких координація здійснюється за участю атома сірки тіонної групи та C=C подвійного зв'язку алільного фррагмента. Розроблені препаративні методи синтезу такого типу комплексних сполук. Склад синтезованих речовин та спосіб координації лігандів встановлені методами елементного аналізу та ${ }^{1}$ H ЯМР спектроскопії. Окрім того, будова комплексів 4, 5 доведена рентгеноструктурним методом. Медико-біологічними дослідженнями встановлено, що комплексні сполуки 5 i 6 in vitro проявляють цитостатичну та цитотоксичну дію на пухлинні клітини лінії HeLa.

КОМПЛЕКСООБРАЗУЮЩАЯ СПОСОБНОСТЬ N-ЗАМЕЩЕННЫХ ПРОИЗВОДНЫХ ТИОМОЧЕВИНЫ КАК ХЕЛАТИРУЮЩИХ ЛИГАНДОВ В РЕАКЦИИ С Рd(II)

Ю.Л.Зборовский, В.В.Орысык, Д.А.Мельниченко, С.И.Орысык, Г.Г.Репич, Л.В.Гарманчук, Л.И.Пальчиковская, В.И.Пехньо, М.В.Вовк

Ключевые слова: C=C двойная связь; координационные соединения палладия; тиомочевина; рентгеноструктурный анализ; п-комплексы; противоопухолевая активность

Исследованы реакции комплексообразования N-замещенных производных тиомочевины с $\mathrm{PdCl}_{2}$. Установлено, что фрункционально замещенные производные тиомочевины являются эфрфективными хелатирующими агентами, при этом природа заместителей существенно влияет на состав и строение комплексных соединений. Так, (N-пиридин-2-ил)тиомочевины при взаимодействии с $\mathrm{PdCl}_{2}$ образуют два типа комплексов в соотношении M:L 1:1 и 1:2, в состав которых эти реагенты входят как S,N-донорные бидентатные лиганды, координируясь к иону палладия атомом серы тионной группы и атомом азота пиридинового ядра. Реакция $\mathrm{N}$-аллилтиомочевин с $\mathrm{PdCl}{ }_{2}$ при эквимолярном соотношении реагентов приводит к образованию п-комплексов, в которых координация осуществляется с участием атома серы тионной группы и C=C двойной связи аллильного фррагмента. Разработаны препаративные методы синтеза этого типа комплексных соединений. Состав синтезированных веществ и способ координации лигандов установлены элементным анализом и методом ${ }^{1}$ Н ЯМР спектроскопии. Кроме того, строение комплексов 4, 5 доказано рентгеноструктурным методом. Медико-биологическими исследованиями установлено, что комплексные соединения 5 и 6 in vitro оказывают цитостатическое и цитотоксическое действие на опухолевые клетки линии HeLa. 
Thiourea and its $\mathrm{N}$-substituted derivatives are efficient complexing agents for metal ions, which are widely used as ligands in coordination chemistry [1-3]. The presence of unshared electron pairs in the sulphur atom and two nitrogen atoms allows to form the complex compounds with transition metal salts of the different type, many of which possess valuable applied properties (optical, semiconductor, biological, etc.) and are employed in various fields of science and technology [4-7]. Thioureas are of prime importance as anticancer drugs due to their ability to inhibit the enzymes that are involved in the malignant tumour formation processes (tyrosine kinase, protein tyrosine kinase and NADH oxidase) [8-10].

In recent 15-20 years much attention has been given to the study of the biological activity of complex compounds of transition and platinum metals [11-15]. Many of them exhibit a high pharmacological activity, and as therapeutic agents are often superior to starting metal salts because the complex formation prevents hydrolysis in the physiologic medium, reduces toxicity and facilitates penetration of medicines through the cell membrane. Moreover, the use of biologically active ligands, an additive or synergistic effect manifests itself between the constituents of complexes $[16,17]$. Therefore, development of methods for the synthesis of different types of complexes based on thiourea derivatives is a promi- sing trend in creating novel therapeutic and diagnostic agents [3, 18-21].

The introduction of additional functional groups into the structure of thioureas (such as allyl, pyridine, morpholine) allows to expand the range of their biological activity and to increase the denticity of these ligand systems, it leads to their competitive coordination to metal ions. On the other hand, palladium as a "soft Lewis acid" has also the competing ability in the interaction with ambidentate ligands by the "soft-soft» type thereby resulting in formation of complexes with different structures depending on the synthetic conditions and the geometrical arrangement of donor atoms in the ligands.

In this work, the effect of synthetic conditions and the denticity of $N$-allyl- $N^{\prime}$-(2-pyridinyl)thiourea $\left(\mathbf{H L}^{\mathbf{1}}\right)$, $\mathrm{N}$-allylmorpholine-4-carbothioamide $\left(\mathbf{H L}^{3}\right)$ and $N$ allyl- $N^{\prime}$-tert-butylthiourea $\left(\mathbf{H L}^{4}\right)$ as ligands on form $\mathrm{N}$-(2-pyridinyl)morpholine-4-carbothioamide $\left(\mathbf{H L}^{2}\right)$, ation of mononuclear coordination compounds with $\mathrm{PdCl}_{2}$ has been studied. In addition, the cytotoxic and proapoptotic activities of $\mathrm{Pd}(\mathrm{II})$ complexes based on $\operatorname{HL}^{3,4}(\mathbf{5}, \mathbf{6})$ were determined.

\section{Results and Discussion}

The complexation reactions were carried out in the acidic medium according to the Scheme. Thioureas $\left(\mathbf{H L}^{1}, \mathbf{H L}^{2}\right)$ contain nucleophilic pyridine nitro-

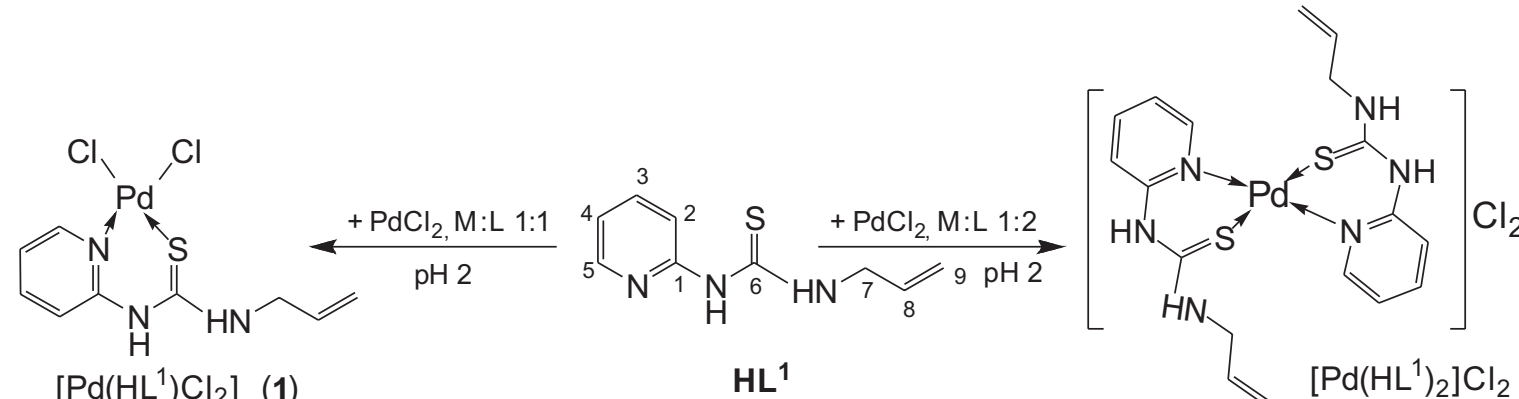

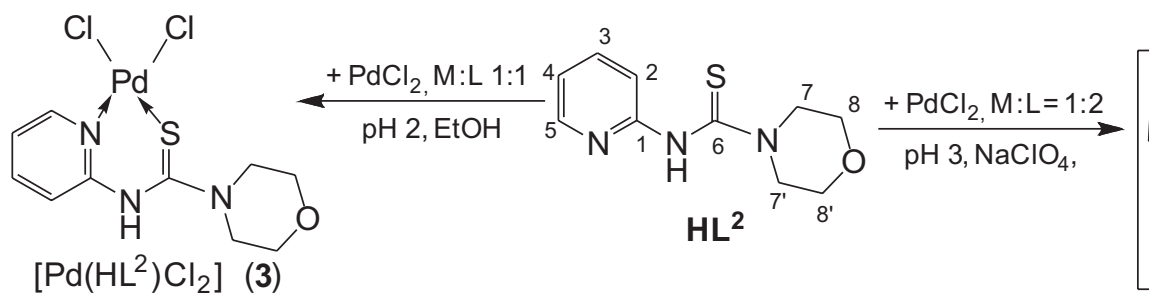<smiles>ClP12(Cl)C=CCNC(N3CCOCC3)=S1C2</smiles>

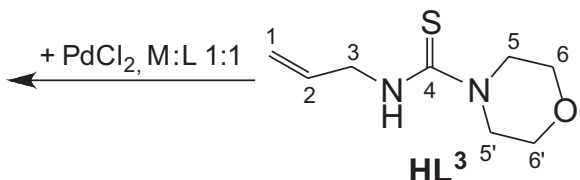<smiles></smiles><smiles>CN1CCOCC1</smiles>

$\left[\mathrm{Pd}\left(\mathrm{HL}^{2}\right)_{2}\right]\left(\mathrm{ClO}_{4}\right)_{2}$

$\left[\mathrm{Pd}\left(\mathrm{HL}^{3}\right) \mathrm{Cl}_{2}\right]$

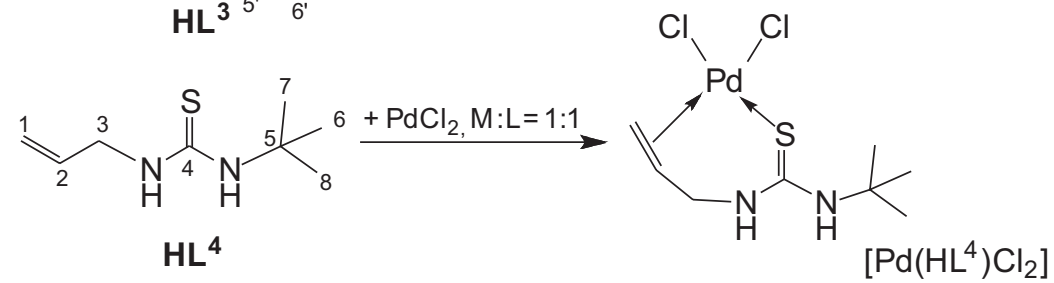




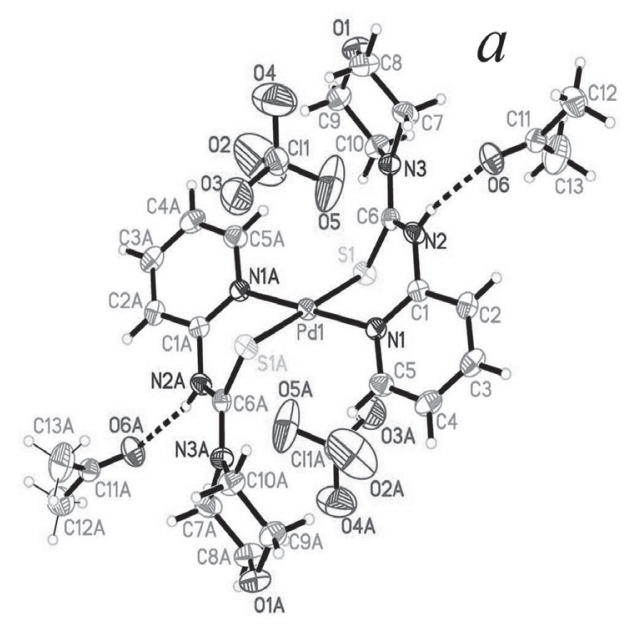

Fig. The molecular structure of complexes $\mathbf{4}(a)$ and $\mathbf{5}(b)$.

gen and sulphur atoms of the carbothioamide group at the stoichiometrically advantageous positions for formation of metallochelates; it results in their coordination to the central metal ion as $\mathrm{S}, \mathrm{N}$-bidentate ligands thereby forming complexes 1-4. At the same time the acid medium contributes to their stay in thionic tautomeric form. Changing the reaction conditions such as temperature, the heating time and the molar ratio affect the number of coordinated ligand molecules and chlorine anions.

Unlike $\mathbf{H L}^{1}, \mathbf{H L}^{2}$, thioureas $\mathbf{H L}^{3}, \mathbf{H} \mathbf{L}^{4}$ contain only one nucleophilic atom (sulphur) capable to coordination, which makes them potential monodentate reagents. However, the ability of palladium to the "softsoft" interaction leads to formation of $n, \pi$-chelate complexes 5, 6. All attempts to synthesize complexes with the molar ratio of 1:2 under the same conditions were unsuccessful. It may be due to the antisymbiosis effect of "soft" allyl and thiourea groups, which makes unfavourable further substitution of "hard" $\mathrm{Cl}^{-}$ ions to "soft" donor atoms of another ligand molecule [22].

All the complexes are soluble in DMSO and DMF, whereas complexes 2, 4-6 are also soluble in water and alcohols.

Single crystal X-ray diffraction study of complexes 4, 5. One molecule of complex 4 per unit cell is observed, and the atom $\operatorname{Pd} 1$ occupies a special position at the centre of inversion. The palladium atom is bound by two $S$ and two N atoms with bond angles N1a-Pd1-N1 $180.0^{\circ}, \mathrm{S} 1 \mathrm{a}-\mathrm{Pd} 1-\mathrm{S} 1180.0^{\circ}, \mathrm{N} 1 \mathrm{a}-\mathrm{Pd} 1-\mathrm{S} 1 \mathrm{a}$ 85.74(7) ${ }^{\circ}$ and N1a-Pd1-S1 94.26(7) ${ }^{\circ}$ in a square-planar coordination geometry (Fig. a). The Pd1-Sl and Pd1-N1 bond lengths are 2.315(8) and 2.029(2) $\AA$, respectively. The bonding parameters agree with the coordinate patterns in [23-25].

The fragment $\mathrm{N} 2 \mathrm{C} 6 \mathrm{~N} 3$ has a planar configuration (the sum of bond angles is $360^{\circ}$ ) and C6-N2 and C6-N3 bond lengths are shorter than that for a standard single $\mathrm{C}-\mathrm{N}$ bond because of conjugation of the lone pair electrons for the nitrogen atoms $\mathrm{N} 2$ and N3 with the double $\mathrm{C}(6)=\mathrm{S}(1)$ bond $(1.731(3) \AA ̊)$. The pyridine ring is planar: the mean deviation from the least-square plane does not exceed $0.011 \AA$ A. The bond angles Pd1-S1-C6 92.98(10) ${ }^{\circ}$, S1-C6-N2 120.1(2) ${ }^{\circ}$, C6-N2-C1 127.4(3) ${ }^{\circ}$, N2-C1-N1 120.2(3) ${ }^{\circ}, \mathrm{C} 1-\mathrm{N} 1-$ Pd1 123.13(18) ${ }^{\circ}$, N1-Pd1-S1 85.74(7) ${ }^{\circ}$ of the six member chelate ring is similar to the corresponding angles in [24] and illustrate that the metallocycle is significantly distorted and has a bath form. The symmetric cycle Pd1/S1a/C6a/N2a/C1a/N1a is analogous. The asymmetric unit also contains a solvate molecule of acetone, which is bonded to the complex by the N2HNH...06 hydrogen bond, with the following parameters: N2...H2N, 0.73(3); HNH...06, 2.15(3); N2H... 06, 2.864(4) $\AA$; N2-H2N-06 166(3) ${ }^{\circ}$. Two perchlorate anions occupy the free space around the palladium atom, and the shortest Pd1-02 distance of the perchlorate anion is $3.747 \AA$.

The asymmetric unit of compound $\mathbf{5}$ involves one solvation water molecule (Fig. b). The central palladium ion forms a square planar coordination unit $\mathrm{Pd}(\mathrm{C}=\mathrm{C})$ $\mathrm{SCl}_{2}$ by atom $\mathrm{S} 1$, two chloride ions $\mathrm{Cl} 1, \mathrm{Cl} 2$ and double bond $\mathrm{C} 1=\mathrm{C} 2$ of the allyl fragment. The midpoint of the $\mathrm{C} 1=\mathrm{C} 2$ double bond is considered as the point ligand with the distance of 2.0451(3) Á to the central metal ion. The average deviation from the absolute

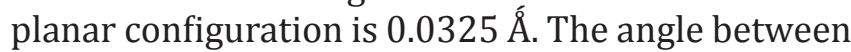
the polyhedral plane and $\mathrm{C} 1-\mathrm{C} 2$ bond is 179 . The bond length C4-S1 (1.741(4) $\AA$ ) indicates to the thione tautomeric form of the coordinated thiourea $\mathbf{H L}^{3}$. The bonds Pd-Cl $(2.322,2.329 \AA \AA)$ in complex $\mathbf{5}$ are equivalent. The analysis of the crystal packing shows a layered structure of complex molecules along the crystallographic axis [010] by the "head-to-tail" type with the extensive system of hydrogen bonds O-H...O 2.897(4) $\AA$, N-H...O 2.759(4) $\AA$ and $\mathrm{O}-\mathrm{H} . . . \mathrm{Cl}$ 3.278(3), 3.350(3) Å.

${ }^{1} \mathrm{H}$ NMR spectra. In the ${ }^{1} \mathrm{H}$ NMR spectra of complexes 1,2 , the signals for $\mathrm{CH}=\mathrm{CH}_{2}$ (allyl) and $\mathrm{N}^{2} \mathrm{H}$ (thioureate group) are shifted upfield by $\Delta \delta=0.104-0.135$ and $1.239 \mathrm{ppm}$, respectively, compared to those in the spectrum of $\mathbf{H L}^{1}$. The considerable upfield shift 
The cytostatic/cytotoxic activity of complex compounds 5, 6

\begin{tabular}{|l|c|c|c|c|c|}
\hline \multirow{2}{*}{ Compound } & \multirow{2}{*}{$\mathrm{IC}_{50}, \mathrm{M}$} & \multirow{2}{*}{$\begin{array}{c}\text { Apoptotic } \\
\text { level, } \%\end{array}$} & \multicolumn{3}{c|}{ Cell cycle phases $(\%),\left(\mathrm{C}_{\text {complex }}=\mathrm{IC}_{50} / 10\right)$} \\
\cline { 4 - 6 } & & 11.8 & $43.45 \pm 1.30$ & $\mathrm{G}_{2} / \mathrm{M}$ & $\mathrm{S}$ \\
\hline Control & - & 80.7 & $67.40 \pm 1.12$ & $6.67 \pm 0.41$ & 34.40 \\
\hline Complex 5 & $1.5 \cdot 10^{-4}$ & 31.3 & $48.85 \pm 0.22$ & $29.51 \pm 1.14$ & $21.63 \pm 1.29$ \\
\hline Complex 6 & $2 \cdot 10^{-6}$ & & & \\
\hline
\end{tabular}

of the signal for $\mathrm{N}^{2} \mathrm{H}$ is due to its participation in forming the six-membered chelate ring $\mathrm{Pd}-\mathrm{N}^{1}-\mathrm{C}^{1}$ $\mathrm{N}^{2} \mathrm{H}-\mathrm{C}^{6}-\mathrm{S}$ (Scheme). The fairly substantial downfield shifts of the signals for the pyridine protons can also be attributed to the coordination of $\mathbf{H L}^{\mathbf{1}}$ by the pyridine $\mathrm{N}$ atom. It should be noted that the protons $\mathrm{C}^{5} \mathrm{H}_{\mathrm{Py}}$ $(\Delta \delta=0.766), \mathrm{C}^{2} \mathrm{H}_{\mathrm{Py}}(\Delta \delta=0.296), \mathrm{C}^{3} \mathrm{H}_{\mathrm{Py}}(\Delta \delta=0.266)$ and $\mathrm{C}^{4} \mathrm{H}_{\mathrm{Py}}(\Delta \delta=0.192 \mathrm{ppm})$, which are in ortho and para position to the coordination bond $\left(\mathrm{N}_{\mathrm{Py}} \rightarrow \mathrm{Pd}\right)$ are most sensitive to the complexation. This is in full agreement with the current approach to location of the coordination bond using the heteronuclear NMR method [26].

The ${ }^{1} \mathrm{H}$ NMR spectrum of the $\mathbf{H L}^{2}$ shows the signals at 7.05, 7.60, 7.70 and $8.28 \mathrm{ppm}$, which are assigned to the pyridine ring protons. A broad singlet corresponding to one proton at $9.85 \mathrm{ppm}$ is assigned to the NH group. The morpholine protons give two triplets at 3.64 and $3.89 \mathrm{ppm}$, which correspond to -N$\mathrm{CH}_{2}$ and $-\mathrm{O}-\mathrm{CH}_{2}$ groups, respectively.

In the spectra of complexes $\mathbf{3 , 4}$ all multiplets of the pyridine ring are shifted downfield and observed at 7.42-8.97 ppm, wherein the doublet $\mathrm{H}^{5}$ located near the nitrogen atom undergoes significantly more downfield shift ( $\Delta \delta=0.69 \mathrm{ppm})$; it indicates the participation of the pyridine ring in the coordination to the metal ion. The $\mathrm{N}^{2} \mathrm{H}$ group is included in the six membered metallocycle, and it causes a significant downfield shift of a broad singlet of this proton by $1.56 / 1.53 \mathrm{ppm}$ and indicates inclusion of the carbothioamide group in the coordination to the metal. The morpholine proton signals are observed at 3.77/3.75 $\left(-\mathrm{N}-\mathrm{CH}_{2}\right)$ and $4.03 / 4.00 \mathrm{ppm}\left(-\mathrm{O}-\mathrm{CH}_{2}\right)$.

The comparison of the $1 \mathrm{H}$ NMR spectra of thioureas $\mathrm{HL}_{3}, \mathrm{HL}_{4}$ and complexes 5, 6 shows that the proton signals of $\mathrm{NH}$ (the thioureate group) and $=\mathrm{C} 2 \mathrm{Hallyl}$ by $\Delta \delta=+1.289 /+1.648,+0.301 /+0.332 \mathrm{ppm}$ undergo the most significant downfield shifts while the multiplet of the allyl fragment $=\mathrm{C} 1 \mathrm{H} 2$ is significant upfield by $-0.544 /-0.824 \mathrm{ppm}$. The most characteristic for the $1 \mathrm{H}$ NMR spectra of these complexes is splitting of the $\mathrm{C} 3 \mathrm{H} 2$ signal to the two doublets.

Cytostatic/cytotoxic screening of complex compounds 5, 6. Being the structural analogues of cisplatin the complex compounds 5, $\mathbf{6}$ were tested in the MTTassay and possessed the cytostatic/cytotoxic activity with $\mathrm{IC}_{50}$ index of $10^{-6}-10^{-4} \mathrm{M}$, (Table) compared to cisplatin $\mathrm{IC}_{50}=1.3 \cdot 10^{-5} \mathrm{M}$ index for HeLa cells [27].
The highest index $\mathrm{IC}_{50}\left(1.5 \cdot 10^{-4} \mathrm{M}\right)$ was determined for the palladium complex with $\mathbf{H L}^{3}$ (5). Both compounds studied had the proapoptotic effect, but in contrast to the highest $\mathrm{IC}_{50}$ index, cytostatic and proapoptotic effects for complex compound 5 were more pronounced. For complexes 5, 6 the apoptotic indexes exceeded the control rate sevenfold and 2.5 times, respectively.

Both compounds possessed the cytostatic and antisynthetic effect. The highest inhibition of cells in both synthetic and mitotic phases $\left(G_{2} / M\right)$ was found for compound 5: the growth of the cell subpopulation in the $\mathrm{G}_{1} / \mathrm{G}_{0}$-phase (1.5 times) was accompanied with reduction of the cell subpopulation in synthetic (1.3 times) and $\mathrm{G}_{2} / \mathrm{M}$ phases (in 3.3 times). The effect of compounds $\mathbf{6}$ on the cell cycle phases in the concentration of $\mathrm{C}_{\text {complex }}=\mathrm{IC}_{50} / 10$ does not differ significantly from the control.

\section{Experimental Part}

The ${ }^{1} \mathrm{H}$ NMR spectra were recorded on a Varian VXR-300 (300 MHz, for $\mathbf{H L}^{\mathbf{1}}, \mathbf{H} \mathbf{L}^{2}$, complexes 1-4) and a Bruker Advance DRX-500 spectrometer $(500.13 \mathrm{MHz}$ for $\mathbf{H L}^{3}, \mathbf{H L}^{4}$, complexes $\mathbf{5}, \mathbf{6}$ ) in DMSO- $\mathrm{d}_{6}$ solution using TMS as an internal standard. The $\mathrm{PdCl}_{2}$ (Pd content $59 \%$, Merck) was used as the starting metal salt. The X-ray structure data of complexes 4,5 were collected at room temperature on a SMART APEX II diffractometer. The thioureas $\mathbf{H L}^{\mathbf{1}} \mathbf{-} \mathbf{H L}^{\mathbf{4}}$ were prepared as described in [28-32].

$\left[\mathbf{P d}\left(\mathbf{H L}^{1}\right) \mathbf{C l}_{\mathbf{2}}\right] \mathbf{( 1 )}$. The synthesis of the complex was carried out in an acidic medium (pH 2.0-2.5) upon moderate $\left(55^{\circ} \mathrm{C}\right)$ heating and constant stirring. Acidify the solution of $\mathrm{PdCl}_{2}$ in ethanol with $4 \mathrm{~N} \mathrm{HCl}$ and add to the solution of thiourea $\mathbf{H L}^{1}$ in ethanol $(\mathrm{Pd}: \mathrm{L}=1: 1)$. Reflux the reaction mixture for $10 \mathrm{~min}$. While cooling filter the yellow precipitate formed, wash with diethyl ether, and dry over $\mathrm{CaCl}_{2}$. Yield $-81 \%$. M.p. $\geq$ $250^{\circ} \mathrm{C}_{\text {decomp. }}{ }^{1} \mathrm{H}$ NMR $\delta$, ppm: 4.18 br.s $\left(2 \mathrm{H}, \mathrm{C}^{7} \mathrm{H}_{2}\right), 5.28$ dd $\left(2 \mathrm{H},=\mathrm{C}^{9} \mathrm{H}_{2}, J=10.5 \mathrm{~Hz}\right.$ and $\left.17.4 \mathrm{~Hz}\right), 5.91 \mathrm{~m}(1 \mathrm{H}$, $\left.=\mathrm{C}^{8} \mathrm{H}\right), 7.24-7.47 \mathrm{~m}\left(2 \mathrm{H}, 2 \mathrm{C}^{2,4} \mathrm{H}_{\mathrm{Py}}\right), 8.05 \mathrm{t}\left(1 \mathrm{H}, \mathrm{C}^{3} \mathrm{H}_{\mathrm{Py}}\right.$ $J=8.1 \mathrm{~Hz}), 9.00 \mathrm{~d}\left(1 \mathrm{H}, \mathrm{C}^{5} \mathrm{H}_{\mathrm{Py}} \mathrm{J}=6.0 \mathrm{~Hz}\right), 9.44 \mathrm{br} . \mathrm{s}(1 \mathrm{H}$, $\left.\mathrm{N}^{2} \mathrm{H}\right), 11.90$ br.s $\left(1 \mathrm{H}, \mathrm{N}^{3} \mathrm{H}\right)$. Found, \%: C 29.35, H 3.05, $\mathrm{Cl}$ 19.34, N 11.37, S 8.82. $\mathrm{C}_{9} \mathrm{H}_{11} \mathrm{Cl}_{2} \mathrm{~N}_{3} \mathrm{SPd}$. Calculated, \%: C 29.19, H 2.97, Cl 19.14, N 11.35, S 8.65.

$\left[\mathbf{P d}\left(\mathbf{H L}^{1}\right)_{2}\right] \mathbf{C l}_{2}(\mathbf{2})$. The synthesis was carried out in the molar ratio of $\mathrm{Pd}: \mathrm{L}=1: 2$ in a similar way to the 
previous complex. Yield - 55\%. M.p. $\geq 230^{\circ} \mathrm{C}_{\text {decomp. }}{ }^{1} \mathrm{H}$ NMR $\delta$, ppm: 4.18 br.s $\left(2 \mathrm{H}, \mathrm{C}^{7} \mathrm{H}_{2}\right), 5.27 \mathrm{dd}\left(2 \mathrm{H},=\mathrm{C}^{9} \mathrm{H}_{2}\right.$, $J=10.5$ and $17.4 \mathrm{~Hz}), 5.86-5.95 \mathrm{~m}\left(1 \mathrm{H},=\mathrm{C}^{8} \mathrm{H}\right), 7.23-$ $7.47 \mathrm{~m}\left(2 \mathrm{H}, 2 \mathrm{C}^{2,4} \mathrm{H}_{\mathrm{Py}}\right), 8.05 \mathrm{t}\left(1 \mathrm{H}, \mathrm{C}^{3} \mathrm{H}_{\mathrm{Py}}, \mathrm{J}=8.1 \mathrm{~Hz}\right), 9.00$ $\mathrm{d}\left(1 \mathrm{H}, \mathrm{C}^{5} \mathrm{H}_{\mathrm{Py}} \mathrm{J}=6.0 \mathrm{~Hz}\right), 9.42$ br.s $\left(1 \mathrm{H}, \mathrm{N}^{2} \mathrm{H}\right), 11.87$ br.s $\left(1 \mathrm{H}, \mathrm{N}^{3} \mathrm{H}\right)$. Found, \%: C 38.35, H 4.0, Cl 12.12, N 14.95, $\mathrm{S}$ 11.22. $\mathrm{C}_{18} \mathrm{H}_{22} \mathrm{Cl}_{2} \mathrm{~N}_{6} \mathrm{~S}_{2} \mathrm{Pd}$. Calculated, \%: C 38.37, $\mathrm{H}$ 3.91, Cl 12.61, N 14.92, S 11.37.

$\left[\mathbf{P d}\left(\mathrm{HL}^{2}\right)_{2} \mathbf{C l}_{2}\right] \cdot \mathbf{2} \mathbf{H}_{2} \mathbf{O}$ (3). Dissolve the powder of $\mathrm{PdCl}_{2}$ (2 mmol, $0.194 \mathrm{~g}$ ) in $0.5 \mathrm{ml}$ of $6 \mathrm{~N} \mathrm{HCl}$ by heating at $60^{\circ} \mathrm{C}$, then dilute to $25 \mathrm{~mL}$ with ethanol. Add dropwise the solution (25 mL) of thiourea $\mathbf{H L}^{2}$ (2 mmol, $0.223 \mathrm{~g}$ ) in ethanol to the $\mathrm{PdCl}_{2}$ solution in the molar ratio of $M: L=1: 1$. Stir the reaction mixture and heat at $80^{\circ} \mathrm{C}$ for about $30 \mathrm{~min}$. Isolate immediately a bright yellow precipitate. Filter the product and wash with small portions of ethanol, $\mathrm{Et}_{2} \mathrm{O}$ and dry in vacuum over $\mathrm{CaCl}_{2}$. Yield $-65 \%$. M.p. $-236^{\circ} \mathrm{C}_{\text {decomp }}{ }^{1} \mathrm{H}$ NMR $\delta$, ppm: $3.77 \mathrm{t}\left(4 \mathrm{H}, 2 \mathrm{C}^{7,7^{\prime}} \mathrm{H}_{2}, J=4.8 \mathrm{~Hz}\right), 4.03 \mathrm{t}\left(4 \mathrm{H}, 2 \mathrm{C}^{8,8^{\prime}} \mathrm{H}_{2}, J=4.7 \mathrm{~Hz}\right)$, $7.42 \mathrm{t}\left(1 \mathrm{H}, \mathrm{C}^{4} \mathrm{H}_{\mathrm{Py}}, J=7.7 \mathrm{~Hz}\right), 7.52 \mathrm{~d}\left(1 \mathrm{H}, \mathrm{C}^{2} \mathrm{H}_{\mathrm{Py}}, J=8.1 \mathrm{~Hz}\right)$, $8.09 \mathrm{t}\left(1 \mathrm{H}, \mathrm{C}^{3} \mathrm{H}_{\mathrm{Py}} \mathrm{J}=7.9 \mathrm{~Hz}\right), 8.97 \mathrm{~d}\left(1 \mathrm{H}, \mathrm{C}^{5} \mathrm{H}_{\mathrm{Py}} \mathrm{J}=4.1 \mathrm{~Hz}\right)$, 11.42 br.s $\left(1 \mathrm{H}, \mathrm{N}^{2} \mathrm{H}\right)$. Found, \%: C 27.34, H 4.32, Cl 16.13, N 9.95, S 7.47. $\mathrm{C}_{10} \mathrm{H}_{17} \mathrm{Cl}_{2} \mathrm{~N}_{3} \mathrm{O}_{3}$ SPd. Calculated, \%: C 27.52, $\mathrm{H} 3.90, \mathrm{Cl} 16.28, \mathrm{~N} 9.63, \mathrm{~S} 7.34$.

$\left[\mathbf{P d}\left(\mathrm{HL}^{2}\right)_{2}\right]\left(\mathrm{ClO}_{4}\right)_{2} \cdot \mathbf{2 C}_{3} \mathbf{H}_{6} \mathbf{O}(\mathbf{4})$. Dissolve the powder of $\mathrm{PdCl}_{2}(1 \mathrm{mmol}, 0.097 \mathrm{~g})$ in $0.1 \mathrm{~mL}$ of $6 \mathrm{~N} \mathrm{HCl}$ by heating at $60{ }^{\circ} \mathrm{C}$, then dilute with acetone to $25 \mathrm{~mL}$. Add dropwise the solution (25 $\mathrm{mL}$ ) of thiourea $\mathbf{H L}^{2}$ ( $2 \mathrm{mmol}, 0.223 \mathrm{~g}$ ) in acetone to the $\mathrm{PdCl}_{2}$ solution. After that add $\mathrm{NaClO}_{4}(0.2 \mathrm{~g})$ to the mixture obtained. Stir the reaction mixture and heat at $55^{\circ} \mathrm{C}$ for about $30 \mathrm{~min}$, and then place into a desiccator with diethyl ether. After a few days of standing, yellow crystals are grown. Yield - 36\% (0.123 g). M.p. $-207^{\circ} \mathrm{C}_{\text {decomp. }}$ ${ }^{1} \mathrm{H}$ NMR $\delta$, ppm: $3.75 \mathrm{t}\left(4 \mathrm{H}, 2 \mathrm{C}^{7,7} \mathrm{H}_{2}, J=4.9 \mathrm{~Hz}\right), 4.00 \mathrm{t}$ $\left(4 \mathrm{H}, 2 \mathrm{C}^{8,8^{\prime}} \mathrm{H}_{2}, J=4.8 \mathrm{~Hz}\right), 7.41 \mathrm{dd}\left(1 \mathrm{H}, \mathrm{C}^{4} \mathrm{H}_{\mathrm{Py}}, J=3.8\right.$ and 7.5 $\mathrm{Hz}), 7.51 \mathrm{~d}\left(1 \mathrm{H}, \mathrm{C}^{2} \mathrm{H}_{\mathrm{Py}}, J=8.2 \mathrm{~Hz}\right), 8.09 \mathrm{dd}\left(1 \mathrm{H}, \mathrm{C}^{3} \mathrm{H}_{\mathrm{Py}}\right.$ $J=2.1$ and $7.8 \mathrm{~Hz}), 8.98 \mathrm{~d}\left(1 \mathrm{H}, \mathrm{C}^{5} \mathrm{H}_{\mathrm{Py}} J=3.9 \mathrm{~Hz}\right), 11.48$ br.s $\left(1 \mathrm{H}, \mathrm{N}^{2} \mathrm{H}\right)$. Found, \%: C 35.84, H 5.63, Cl 8.04, $\mathrm{N}$ 9.81, S 7.44. $\mathrm{C}_{26} \mathrm{H}_{38} \mathrm{Cl}_{2} \mathrm{~N}_{6} \mathrm{O}_{12} \mathrm{~S}_{2} \mathrm{Pd}$. Calculated, \%: C 35.97, H 4.41, Cl 8.19, N 9.68, S 7.39.

$\left[\mathbf{P d}\left(\mathrm{HL}^{3}\right) \mathbf{C l}_{2}\right] \cdot \mathbf{H}_{2} \mathbf{O}$ (5). Dissolve the powder of $\mathrm{PdCl}_{2}$ (44.2 mg, $0.25 \mathrm{mmol}$ ) in the mixture of $10 \mathrm{ml} \mathrm{EtOH}$ and $2 \mathrm{ml} 2 \mathrm{~N} \mathrm{HCl}$. Add dropwise the ethanol solution (10 $\mathrm{mL}$ ) of thiourea $\mathbf{H L}^{3}$ (46.6 $\mathrm{mg}, 0.25 \mathrm{mmol}$ ) to the resulting $\mathrm{PdCl}_{2}$ solution under constant stirring. Stir the mixture and heat at $30-35^{\circ} \mathrm{C}$ for $10 \mathrm{~min}$ and leave for crystallization. Orange needle-shaped thin crystals are formed next day. Filter crystals and wash with ethanol and diethyl ether. Yield - 81\% (77 mg). ${ }^{1} \mathrm{H}$ NMR $\delta$, ppm: 3.76-3.67 m (8H, 2 $\left.\mathrm{C}^{5,5^{\prime}} \mathrm{H}_{2}+2 \mathrm{C}^{6,6^{\prime}} \mathrm{H}_{2}\right), 3.99$ $\mathrm{d}\left(1 \mathrm{H}, \mathrm{C}^{3} \mathrm{H}_{2}, \mathrm{~J}=18.7 \mathrm{~Hz}\right), 4.25 \mathrm{~d}\left(1 \mathrm{H}, \mathrm{C}^{3} \mathrm{H}_{2}, J=18.7 \mathrm{~Hz}\right)$, $4.59 \mathrm{~d}\left(1 \mathrm{H},=\mathrm{C}^{1} \mathrm{H}_{\text {trans }} \mathrm{J}=14.0 \mathrm{~Hz}\right), 4.94 \mathrm{~d}\left(1 \mathrm{H},=\mathrm{C}^{1} \mathrm{H}_{\text {cis }} J=7.5\right.$ $\mathrm{Hz}), 6.17 \mathrm{~m}\left(1 \mathrm{H},=\mathrm{C}^{2} \mathrm{H}\right), 9.16 \mathrm{~s}(1 \mathrm{H}, \mathrm{NH})$. Found: $\mathrm{C} 24.94, \mathrm{H}$ 4.02, Cl 18.65, N 7.48, S 8.32. $\mathrm{C}_{8} \mathrm{H}_{16} \mathrm{Cl}_{2} \mathrm{~N}_{2} \mathrm{O}_{2} \mathrm{PdS}$. Calculated, \%: C 25.18, H 4.23, Cl 18.58, N 7.34, S 8.40.

[Pd( $\left.\left.\mathbf{P L}{ }^{4}\right) \mathbf{C l}_{2}\right](6)$. Dissolve the powder of $\mathrm{PdCl}_{2}$ (44.2 $\mathrm{mg}, 0.25 \mathrm{mmol}$ ) in the mixture of $10 \mathrm{ml} \mathrm{EtOH}$ and $2 \mathrm{ml} 2 \mathrm{~N} \mathrm{HCl}$. Add dropwise the ethanol solution (10 ml) of thiourea $\mathbf{H L}^{4}$ (43.0 $\mathrm{mg}, 0.25 \mathrm{mmol}$ ) to the $\mathrm{PdCl}_{2}$ solution under constant stirring. In an hour filter a bit cloudy solution obtained and leave the resulting clear light-orange solution for crystallization. Red-brown prism-shaped crystals are formed in 2 days. Filter crystals and wash with ethanol and diethyl ether. Yield - 86\% (75 mg). ${ }^{1} \mathrm{H}$ NMR $\delta$, ppm: $1.36 \mathrm{~s}$ $\left(9 \mathrm{H}, 3 \mathrm{C}^{6,7,8} \mathrm{H}_{3}\right), 4.06 \mathrm{~d}\left(1 \mathrm{H}, \mathrm{C}^{3} \mathrm{H}_{2}, J=17.0 \mathrm{~Hz}\right), 4.20 \mathrm{~d}(1 \mathrm{H}$, $\left.\mathrm{C}^{3} \mathrm{H}_{2}, J=18.0 \mathrm{~Hz}\right), 4.33 \mathrm{~d}\left(1 \mathrm{H},=\mathrm{C}^{1} \mathrm{H}_{\text {trans }} \mathrm{J}=14.5 \mathrm{~Hz}\right) ; 4.96$ $\mathrm{d}\left(1 \mathrm{H},=\mathrm{C}^{1} \mathrm{H}_{\text {cis }}, J=7.5 \mathrm{~Hz}\right), 6.16 \mathrm{~m}\left(1 \mathrm{H},=\mathrm{C}^{2} \mathrm{H}\right), 8.34 \mathrm{~s}$ $(1 \mathrm{H}, \mathrm{NH}), 8.91 \mathrm{~s}\left(1 \mathrm{H}, \mathrm{N}^{2} \mathrm{H}\right)$. Found, \%: C 27.2, H 4.5, Cl 20.22, N 8.16, S 9.25. $\mathrm{C}_{8} \mathrm{H}_{16} \mathrm{Cl}_{2} \mathrm{~N}_{2}$ PdS. Calculated, \%: C 27.48, H 4.61, Cl 20.28, N 8.01, S 9.17.

\section{Conclusions}

1. (N-pyridine-2-yl)thioureas react with $\mathrm{PdCl}_{2}$ thereby forming the chelate-type complex compounds, in which ligands bind the metal ion by the sulphur atom of the thione group and the nitrogen atom of the pyridine ring.

2. An analogous reaction of $\mathrm{N}$-allylthioureas results in formation of $\pi$-complexes involving the thione sulphur atom and the $\mathrm{C}=\mathrm{C}$ double bond of the allylic moiety in coordination to palladium(II) ions.

3 . The biological screening for Pd(II) $\pi$-complexes of the $N$-allylthiourea derivatives has exhibited in vitro their pronounced antitumor activity.

\section{References}

1. Saeeda A., Flörke U., Erben M. F. Journal of Sulfur Chemistry, 2013. DOI: 10.1080/17415993.2013.834904.

2. Özer C. K., Arslan H., VanDerveer D., Külcü N. Molecules, 2009, Vol. 14, No.2, pp.655-666.

3. Saeed S., Rashid N., Ali M., Hussain R. European Journal of Chemistry, 2010, Vol. 1, No.3, pp.200-205.

4. Kumar S. M. R., Selvakumar S., Kubendiran T., Selvam M., Elakiya R. V. T., Vimalan M. Archives of Applied Science Research, 2011 , Vol. 3, No.1, pp.145-153.

5. Maadeswaran P., Thirumalairajan S., Chandrasekaran J. Optik, 2010, Vol. 121, No.17, pp.1620-1624.

6. Madarász J., Bombicz P., Okuya M., Kaneko S. Solid State Ionics, 2001, Vol. 141-142, pp.439-446.

7. Bombicz P., Mutikainen I., Krunks M., Leskelä T., Madarász J., Niinistö L. Inorganica Chimica Acta, 2004, Vol. 357, No.2, pp.513-525.

8. Kumar V., Chimni S. S. Anti-Cancer Agents in Medicinal Chemistry, 2015, Vol. 15, No.2, pp.163-175.

9. Li H.-Q., Yan T., Yang Y., Shi L., Zhou C.-F., Zhu H.-L. Bioorganic \& Medicinal Chemistry, 2010, Vol. 18, No.1, pp.305-313.

10. Lv P.-C., Li H.-Q., Sun J., Zhou Y., Zhu H.-L. Bioorganic \& Medicinal Chemistry, 2010, Vol. 18, No.13, pp.4606-4614.

11. Rafique S., Idrees M., Nasim A., Akbar H., Athar A. Biotechnology and Molecular Biology Reviews, 2010, Vol. 5, No.2, pp.38-45.

12. Sun R. W.-Y., Ma D.-L., Wong E. L.-M., Che C.-M. Dalton Transactions, 2007, No.43, pp.4884-4882.

13. Zhang C. X., Lippard S. J. Current Opinion in Chemical Biology, 2003, Vol. 7, No.4, pp.481-489.

14. Kostova I. Recent Patents on Anti-Cancer Drug Discovery, 2006, Vol. 1, No.1, pp.1-22.

15. Puckett C. A., Ernst R. J., Barton J. K. J. Chem. Soc., Dalton Transactions, 2010, Vol. 39, No.5, pp.1159-1170. 
16. Nita S., Andries A. A., Patron L., Albulescu R., Radulescu F., Tanase C., Vintila M. Revista de Chimie (Bucharest), 2011 , Vol. 62, No.5, pp.549-553.

17. Margiotta N., Denora N., Ostuni R., Laquintana V., Anderson A., Johnson S., W., Trapani G., Natile G. Journal of Medicinal Chemistry, 2010, Vol. 53, No.14, pp.5144-5154.

18. Yan K., Lok C.-N., Bierla K., Che C.-M. Chemical Communications, 2010, Vol. 46, No.41, pp.7691-7693.

19. Marverti G., Cusumano M., Ligabue A., Di Pietro M. L., Vainiglia P. A., Ferrari A., Bergomi M., Moruzzi M. S., Frassineti C. Journal of Inorganic Biochemistry, 2008, Vol. 102, No.4, pp.699-712.

20. D'Cruz O. J., Dong Y., Uckun F. M. Biochemical and Biophysical Research Communications, 2003, Vol. 302, No.2, pp.253-264.

21. Del Campo R., Criado J. J., Gheorghe R., González F. J., Hermosa M. R., Sanz F., Manzano J. L., Monte E., Rodrígues-Fernández E. Journal of Inorganic Biochemistry, 2004, Vol. 98, No.8, pp.1307-1314.

22. Pearson R. G. Inorganic Chemistry, 1973, Vol. 12, No.3, pp.712-713.

23. Avsar G., Arslan H. Turkish Journal of Chemistry, 2003, Vol. 27, No.3, pp.281-285.

24. Schroder U., Richter R., Beyer L., Angulo-Cornejo J., Lino-Pacheco M., Guillen A. Zeitschrift für anorganische und allgemeine Chemie, 2003, Vol. 629, No.6, pp.1051-1058.

25. Joseph M., Kuriakose M., Kurup M. R. P., Suresh E., Kishore A., Bhat S. G. Polyhedron, 2006, Vol. 25, No.1, pp.61-70.

26. Бородкин Г. С., Бородкина И. Г., Ураев А. И., Васильченко И. С., Садеков И. Д., Гарновский А. Д. Российский химический журнал, 2004, Т. 58, №1, c.117-124.

27. Tardito S., Isella C., Medico E., Marchioò L., Bevilacqua E., Hatzoglou M., Bussolati O., Franchi-Gazzola R. The Journal of Biological Chemistry, Vol. 284, No.36, pp.24306-24319.

28. Zborovskii Yu. L., Orysyk V. V., Staninets V. I., Rusanov E. B., Chernega A. N. Russian Journal of Organic Chemistry, 2007, Vol. 43, No.7, pp.1030-1034.

29. Bon V. V., Orysyk S. I., Pekhnyo V. I., Orysyk V. V., Volkov S. V. Polyhedron, 2007, Vol. 26, No.13, pp.2935-2941.

30. Kjaer A., Rubinstein K. Acta Chemica Scandinavica, 1953, Vol. 7, No.3, pp.528-536.

31. Henry R. A., Dehn W. M. Journal of the American Chemical Society, 1950, Vol. 72, No.6, pp.2806-2807.

32. Custelcean R., Gorbunova M. G., Bonnesen P. V. Chemistry - A European Journal, 2005, Vol. 11, No.5, pp.1459-1466.

Надійшла до редакції 06.11.2015 р. 